$\mathbb{P}$ periodica polytechnica

Civil Engineering

$55 / 2(2011) 177+189$

doi: 10.3311/pp.ci.2011-2.10

web: http://www.pp.bme.hu/ci

(c) Periodica Polytechnica 2011

RESEARCH ARTICLE

\section{Tests experiences in small radius curves of continuously welded rail tracks}

József Szabó

Received 2011-04-08, revised 2011-05-17, accepted 2011-06-01

\begin{abstract}
The continuously welded rail tracks are very popular and wide because of their advantages. Although the continuously welded rail tracks have special mechanical properties and requirements and they need special construction and maintenance. One of the most important requirements of the continuously welded rail tracks is the big lateral resistance. The lateral resistance can be increased by several solutions, which are highlighted in the following three methods: ballast bonding technology and safety caps and $Y$ steel sleepers. The main goal of this publication is to demonstrate the tests and measurements made in three different track sections, to compare and analyze the results of the measurements and to summarize the conclusions.
\end{abstract}

\section{Keywords}

continuously welded rail track $\cdot$ small radius curve $\cdot$ lateral resistance $\cdot$ ballast bonding technology $\cdot$ safety cap $\cdot Y$ steel sleeper $\cdot$ track measurement $\cdot$ track geometry $\cdot$ geometric condition

\section{József Szabó}

Budapest University of Technology and Economics, Department of Highway and Railway Engineering, H-1111 Budapest, MǗegyetem rkp. 3. K. mf. 26., Hungary

e-mail: szabojozsef@uvt.bme.hu

\section{Introduction}

Since the appearance of the railway, demands for higher speed and ride comfort are continuously increasing. Therefore the railway has to be also developed continuously. In this development the appearance of the continuously welded rail tracks was a very important step. The main advantage of the continuously welded rail tracks is that the fish plated joints disappear with their disadvantages. The maintenance of the fish plated joints is unnecessary, the number of the vertical and horizontal steps reduces and the deflections of the rail ends disappear. Consequently the lifetime of the railway superstructures and railway vehicles increases. They together result decrease of the track maintenance costs, higher travel safety and higher ride comfort. The number and length of the continuously welded rail tracks should be increased because of their advantages. It can be done by construction of new continuously welded rail tracks or reconstruction of existing rail joined tracks. Naturally in these cases, the special mechanical properties and requirements of the continuously welded rail tracks have to be considered at all events.

The most critical parts of the continuously welded rail tracks are the small radius curves because the risk of buckling is the biggest in the small radius curves. The buckling is very dangerous therefore it must be prevented at all events [1-5]. For this reason the stability of the continuously welded rail tracks is very important [6,7]. The main element of the stability is the lateral resistance of the track $[8,9]$. The lateral resistance of the continuously welded rail tracks can be increased by several solutions, which are highlighted in the following three methods:

- Track stabilization by ballast bonding technology, especially with lateral structural bonding.

- Track building with sleepers fixed by safety caps.

- Track building with Y steel sleepers.

Each of the three different methods can increase the lateral resistance. Previously there were studies and researches separately in connection with ballast bonding technology [10,11] and in connection with Y steel sleepers [12-14], but these methods have not been compared yet. For this reason the main goal of the 
tests was to compare the efficiency of these methods. Therefore track measurements were made in three different track sections. The first track section is stabilized by ballast bonding, the second track section is fixed with safety caps and the third track section is built with Y steel sleepers. Each of the three track sections are in small radius curves and in continuously welded rail tracks. During the first test the displacements of the elements of the track superstructure were measured under loading of a locomotive. During the second test the geometric conditions of the tracks were examined. The results were compared and analyzed.

\section{Technical presentation of the test track sections}

2.1 Technical presentation of the track section stabilized by ballast bonding

The track section stabilized by ballast bonding lies in the Szabadbattyán - Tapolca railway line (number 29), near to Balatonrendes station, between sections 947+93-954+07. The geometry of the track section is a small radius curve with transition curves. The superstructure of the track section is a continuously welded rail track. The ballast bonding technology was applied between sections $947+65-952+25$. The sizes of the bonding (lateral structural bonding) were $40 \mathrm{~cm}$ width and $20 \mathrm{~cm}$ depth, on the outside of the curve. The geometric and structural data of the track section are in Table 1

Tab. 1. The geometric and structural data of the track section stabilized by ballast bonding

\begin{tabular}{|c|c|}
\hline Beginning of the first transition curve & $947+93$ section \\
\hline End of the first transition curve & $948+57$ section \\
\hline End of the second transition curve & $953+39$ section \\
\hline Beginning of the second transition curve & $954+07$ section \\
\hline Radius of the curve & $\mathrm{R}=300 \mathrm{~m}$ \\
\hline Length of the circular curve & $I_{R}=482 \mathrm{~m}$ \\
\hline Length of the first transition curve & $\begin{array}{c}L_{1}=64 \mathrm{~m} \text { (chlothoid transition } \\
\text { curve) }\end{array}$ \\
\hline Length of the second transition curve & $\begin{array}{c}L_{2}=68 \mathrm{~m} \text { (chlothoid transition } \\
\text { curve) }\end{array}$ \\
\hline Value of the super elevation & $m=79 \mathrm{~mm}$ \\
\hline Distance between the sleepers & $k=55$ and $57 \mathrm{~cm}$ \\
\hline Allowed speed & $V=60 \mathrm{~km} / \mathrm{h}$ \\
\hline Rail profile & MÁV 48 \\
\hline Type of the rail fastenings & GEO \\
\hline Type of the sleepers & L and LI type concrete sleepers \\
\hline Type of the ballast bed & $\begin{array}{c}52 \mathrm{~cm} \text { thick crushed stone } \\
\text { ballast bed }\end{array}$ \\
\hline Widening of the ballast bed & $\begin{array}{c}65 \mathrm{~cm} \text { on the outside of the } \\
\text { curve }\end{array}$ \\
\hline Type of the superstructure & Continuously welded rail track \\
\hline
\end{tabular}

2.2 Technical presentation of the track section fixed with safety caps

The track section fixed with safety caps lies in the Szabadbattyán - Tapolca railway line (number 29), near to Balaton- füzfö station, between sections $451+16-454+01$. The geometry of the track section is a small radius curve with transition curves. The superstructure of the track section is a continuously welded rail track. The safety caps were applied between sections $451+35-460+15$. The safety caps were installed to every sleeper. The geometric and structural data of the track section are in Table 2

Tab. 2. The geometric and structural data of the track section fixed with safety caps

\begin{tabular}{cc}
\hline Beginning of the first transition curve & $451+16$ section \\
\hline End of the first transition curve & $451+72$ section \\
End of the second transition curve & $453+46$ section \\
Beginning of the second transition curve & $454+01$ section \\
Radius of the curve & $R=300 \mathrm{~m}$ \\
Length of the circular curve & $I_{R}=174 \mathrm{~m}$ \\
Length of the first transition curve & $L_{1}=56 \mathrm{~m}$ (chlothoid transition \\
& curve) \\
Length of the second transition curve & $L_{2}=55 \mathrm{~m}$ (chlothoid transition \\
Value of the super elevation & curve) \\
Distance between the sleepers & $k=55$ and $57 \mathrm{~cm}$ \\
Allowed speed & $V=60 \mathrm{~km} / \mathrm{h}$ \\
Rail profile & MÁV 48 \\
Type of the rail fastenings & GEO \\
Type of the sleepers & LI type concrete sleepers \\
Type of the ballast bed & $52 \mathrm{~cm}$ thick crushed stone \\
& ballast bed \\
Widening of the ballast bed & $65 \mathrm{~cm}$ on the outside of the \\
Type of the superstructure & curve
\end{tabular}

\subsection{Technical presentation of the track section built with $Y$ steel sleepers}

The track section built with Y steel sleepers lies in the Szabadbattyán - Tapolca railway line (number 29), near to Badacsony station, between sections $1039+31-1043+39$. The geometry of the track section is a small radius curve with transition curves. The superstructure of the track section is a continuously welded rail track. The Y steel sleepers were applied between sections $1039+36-1043+34$. The type of the $\mathrm{Y}$ steel sleepers is 230 $-650-230$. In the track section there are 300 normal $\mathrm{Y}$ steel sleepers and 2 transition $\mathrm{Y}$ steel sleepers. The geometric and structural data of the track section are in Table 3 .

\section{Test of the displacements of the elements of the track superstructure under dynamic loading of a locomotive}

\subsection{The implementation of the measurements}

During the track measurements the following displacements were measured under loading of a locomotive:

- Absolute vertical displacement of the sleeper.

- Absolute lateral horizontal displacement of the sleeper.

- Relative vertical displacement of the flange on the outside rail. 
Tab. 3. The geometric and structural data of the track section built with $Y$ steel sleepers

\begin{tabular}{|c|c|}
\hline Beginning of the first transition curve & $1039+31$ section \\
\hline End of the first transition curve & $1039+99$ section \\
\hline End of the second transition curve & $1042+71$ section \\
\hline Beginning of the second transition curve & $1043+39$ section \\
\hline Radius of the curve & $R=300 \mathrm{~m}$ \\
\hline Length of the circular curve & $I_{R}=272 \mathrm{~m}$ \\
\hline Length of the first transition curve & $\begin{array}{c}L_{1}=68 \mathrm{~m} \text { (chlothoid transition } \\
\text { curve) }\end{array}$ \\
\hline Length of the second transition curve & $\begin{array}{c}L_{2}=68 m \text { (chlothoid transition } \\
\text { curve) }\end{array}$ \\
\hline Value of the super elevation & $m=93 \mathrm{~mm}$ \\
\hline Allowed speed & $V=60 \mathrm{~km} / \mathrm{h}$ \\
\hline Rail profile & MÁV 48 \\
\hline Type of the rail fastenings & S 15 \\
\hline Type of the sleepers & $\begin{array}{c}230-650-230 \text { type } Y \text { steel } \\
\text { sleepers }\end{array}$ \\
\hline First transition Y steel sleeper & 1039+36 section \\
\hline Last transition Y steel sleeper & $1043+34$ section \\
\hline Type of the ballast bed & Crushed stone ballast bed \\
\hline Type of the superstructure & Continuously welded rail track \\
\hline
\end{tabular}

- Relative lateral horizontal displacement of the head on the outside rail.

The measurements were made at the following places:

- The track section stabilized by ballast bonding: in the sections $949+76$ and $951+55$, total on 4 concrete sleepers.

- The track section fixed with safety caps: in the sections $452+20$ and $452+70$, total on 4 concrete sleepers.

- The track section built with Y steel sleepers: in the sections $1040+70,1041+33$ and $1042+28$, total on 6 Y steel sleepers.

The absolute displacements of the sleepers and the relative displacements of the outside rail were measured under dynamic loading of one M41 type locomotive. During the measurements the locomotive passed over all measuring gauges with speed $5 \mathrm{~km} / \mathrm{h}, 40 \mathrm{~km} / \mathrm{h}$ and $60 \mathrm{~km} / \mathrm{h}$. There were a minimum of 6 series at each speed. The displacements were measured with inductive displacement sensors. The signals of the inductive displacement sensors were conducted to an amplifier and scan device. The sampling frequency was $300 \mathrm{~Hz}$ and $1200 \mathrm{~Hz}$ depending on the speed of the locomotive. The high frequency signals were smoothed by digital algorithm. The filtration frequency was $20 \mathrm{~Hz}$.

\subsection{The results of the measurements}

During the measurements of the displacements hundreds of time-displacement functions were received. An example of such a function is shown in Fig. 1. From the functions were calculated the averages of the maximal displacements. The final results of the measurements are summarized for the track section stabilized by ballast bonding in Table 4 for the track section fixed with safety caps in Table 5 and for the track section built with $\mathrm{Y}$ steel sleepers in Table 6[15, 16].

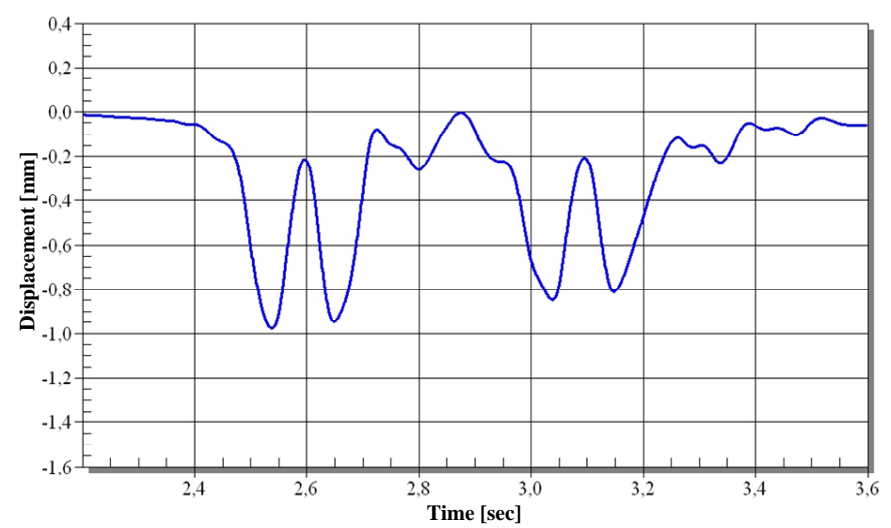

Fig. 1. One of the hundreds of the time-displacement functions

\subsection{Comparison and analysis of the results, statements}

3.3.1 Comparison of the results of the track section stabilized by ballast bonding and of the track section fixed with safety caps

The final results of the track section stabilized by ballast bonding and of the track section fixed with safety caps are summarized in Table 7. The comparison of the results in bar graph format is shown for the speed $5 \mathrm{~km} / \mathrm{h}$ in Fig. 2 for the speed $40 \mathrm{~km} / \mathrm{h}$ in Fig. 3 and for the speed $60 \mathrm{~km} / \mathrm{h}$ in Fig. 4

On the basis of the measurement results of the track section stabilized by ballast bonding and of the track section fixed with safety caps, the main statements are the follows:

The absolute vertical displacements of the sleepers:

- The subsidence of the sleepers in the ballast bed were 0,6 $1,0 \mathrm{~mm}$ in the track section stabilized by ballast bonding and they were $0,7-1,2 \mathrm{~mm}$ in the track section fixed with safety caps.

- The subsidence of the sleepers were bigger on the inside than on the outside in both track sections at all three speeds.

- On the outside the subsidence of the sleepers were similar in the two track sections at all three speeds.

- On the inside the subsidence of the sleepers were smaller in the track section stabilized by ballast bonding than in the track section fixed with safety caps at all three speeds.

The absolute lateral horizontal displacements of the sleepers:

- The lateral horizontal displacements of the sleepers in the ballast bed were $0,3-0,5 \mathrm{~mm}$ in the track section stabilized by ballast bonding and they were $0,5-0,7 \mathrm{~mm}$ in the track section fixed with safety caps.

- The lateral horizontal displacements of the sleepers were smaller in the track section stabilized by ballast bonding than in the track section fixed with safety caps at all three speeds. This means that the lateral resistance of the track section stabilized by ballast bonding is bigger than the lateral resistance of the track section fixed with safety caps.

The relative vertical displacements of the flange on the outside rail:

- The subsidence of the outside rail compared to the sleeper were $0,5-0,8 \mathrm{~mm}$ in the track section stabilized by ballast 
Tab. 4. The final results of the measurements for the track section stabilized by ballast bonding

\begin{tabular}{|c|c|c|c|c|c|c|c|}
\hline \multirow[t]{2}{*}{ Technology } & \multirow[t]{2}{*}{ Speed [km/h] } & \multicolumn{2}{|c|}{$\begin{array}{c}\text { Absolute vertical displacement } \\
\text { of the sleeper }[\mathrm{mm}]\end{array}$} & \multirow{2}{*}{$\begin{array}{c}\text { Absolute } \\
\text { lateral } \\
\text { horizontal } \\
\text { displacement } \\
\text { of the sleeper } \\
\text { [mm] }\end{array}$} & \multirow{2}{*}{$\begin{array}{c}\text { Relative } \\
\text { vertical } \\
\text { displacement } \\
\text { of the flange } \\
\text { (inside) [mm] }\end{array}$} & \multirow{2}{*}{$\begin{array}{c}\text { Relative } \\
\text { vertical } \\
\text { displacement } \\
\text { of the flange } \\
\text { (outside) [mm] }\end{array}$} & \multirow{2}{*}{$\begin{array}{c}\text { Relative } \\
\text { lateral } \\
\text { horizontal } \\
\text { displacement } \\
\text { of the head } \\
\text { [mm] }\end{array}$} \\
\hline & & $\begin{array}{l}\text { Outside of the } \\
\text { curve }\end{array}$ & $\begin{array}{l}\text { Inside of the } \\
\text { curve }\end{array}$ & & & & \\
\hline Ballast & 5 & 0,646 & 0,770 & 0,274 & 0,599 & 0,777 & 0,186 \\
\hline bonding & 40 & 0,746 & 0,867 & 0,354 & 0,573 & 0,703 & 0,208 \\
\hline technology & 60 & 0,804 & 0,948 & 0,471 & 0,547 & 0,663 & 0,259 \\
\hline
\end{tabular}

Tab. 5. The final results of the measurements for the track section fixed with safety caps

\begin{tabular}{|c|c|c|c|c|c|c|c|}
\hline \multirow[t]{2}{*}{ Technology } & \multirow[t]{2}{*}{ Speed [km/h] } & \multicolumn{2}{|c|}{$\begin{array}{c}\text { Absolute vertical displacement } \\
\text { of the sleeper }[\mathrm{mm}]\end{array}$} & \multirow{2}{*}{$\begin{array}{c}\text { Absolute } \\
\text { lateral } \\
\text { horizontal } \\
\text { displacement } \\
\text { of the sleeper } \\
\text { [mm] }\end{array}$} & \multirow{2}{*}{$\begin{array}{c}\text { Relative } \\
\text { vertical } \\
\text { displacement } \\
\text { of the flange } \\
\text { (inside) [mm] }\end{array}$} & \multirow{2}{*}{$\begin{array}{c}\text { Relative } \\
\text { vertical } \\
\text { displacement } \\
\text { of the flange } \\
\text { (outside) [mm] }\end{array}$} & \multirow{2}{*}{$\begin{array}{c}\text { Relative } \\
\text { lateral } \\
\text { horizontal } \\
\text { displacement } \\
\text { of the head } \\
\text { [mm] }\end{array}$} \\
\hline & & $\begin{array}{l}\text { Outside of the } \\
\text { curve }\end{array}$ & $\begin{array}{l}\text { Inside of the } \\
\text { curve }\end{array}$ & & & & \\
\hline \multirow[t]{3}{*}{ Safety caps } & 5 & 0,669 & 1,043 & 0,462 & 0,685 & 0,884 & 0,201 \\
\hline & 40 & 0,778 & 1,179 & 0,569 & 0,657 & 0,793 & 0,221 \\
\hline & 60 & 0,827 & 1,210 & 0,694 & 0,624 & 0,750 & 0,269 \\
\hline
\end{tabular}

Tab. 6. The final results of the measurements for the track section built with Y steel sleepers

\begin{tabular}{|c|c|c|c|c|c|c|c|}
\hline \multirow[t]{2}{*}{ Technology } & \multirow[t]{2}{*}{ Speed [km/h] } & \multicolumn{2}{|c|}{$\begin{array}{c}\text { Absolute vertical displacement } \\
\text { of the sleeper [mm] }\end{array}$} & \multirow{2}{*}{$\begin{array}{c}\text { Absolute } \\
\text { lateral } \\
\text { horizontal } \\
\text { displacement } \\
\text { of the sleeper } \\
\text { [mm] }\end{array}$} & \multirow{2}{*}{$\begin{array}{c}\text { Relative } \\
\text { vertical } \\
\text { displacement } \\
\text { of the flange } \\
\text { (inside) [mm] }\end{array}$} & \multirow{2}{*}{$\begin{array}{c}\text { Relative } \\
\text { vertical } \\
\text { displacement } \\
\text { of the flange } \\
\text { (outside) [mm] }\end{array}$} & \multirow{2}{*}{$\begin{array}{c}\text { Relative } \\
\text { lateral } \\
\text { horizontal } \\
\text { displacement } \\
\text { of the head } \\
\text { [mm] }\end{array}$} \\
\hline & & $\begin{array}{l}\text { Outside of the } \\
\text { curve }\end{array}$ & $\begin{array}{l}\text { Inside of the } \\
\text { curve }\end{array}$ & & & & \\
\hline Y steel & 5 & 1,449 & 1,621 & 0,127 & 0,198 & 0,715 & 0,446 \\
\hline \multirow[t]{2}{*}{ sleepers } & 40 & 1,652 & 1,841 & 0,207 & 0,038 & 0,476 & 0,338 \\
\hline & 60 & 1,600 & 1,764 & 0,250 & 0,099 & 0,474 & 0,336 \\
\hline
\end{tabular}

Tab. 7. The final results of the track section stabilized by ballast bonding and of the track section fixed with safety caps

\begin{tabular}{|c|c|c|c|c|c|c|c|}
\hline \multirow[t]{2}{*}{ Technology } & \multirow[t]{2}{*}{ Speed $[\mathrm{km} / \mathrm{h}]$} & \multicolumn{2}{|c|}{$\begin{array}{c}\text { Absolute vertical displacement } \\
\text { of the sleeper [mm] }\end{array}$} & \multirow{2}{*}{$\begin{array}{c}\text { Absolute } \\
\text { lateral } \\
\text { horizontal } \\
\text { displacement } \\
\text { of the sleeper } \\
\text { [mm] }\end{array}$} & \multirow{2}{*}{$\begin{array}{c}\text { Relative } \\
\text { vertical } \\
\text { displacement } \\
\text { of the flange } \\
\text { (inside) [mm] }\end{array}$} & \multirow{2}{*}{$\begin{array}{c}\text { Relative } \\
\text { vertical } \\
\text { displacement } \\
\text { of the flange } \\
\text { (outside) [mm] }\end{array}$} & \multirow{2}{*}{$\begin{array}{c}\text { Relative } \\
\text { lateral } \\
\text { horizontal } \\
\text { displacement } \\
\text { of the head } \\
\text { [mm] }\end{array}$} \\
\hline & & $\begin{array}{l}\text { Outside of the } \\
\text { curve }\end{array}$ & $\begin{array}{l}\text { Inside of the } \\
\text { curve }\end{array}$ & & & & \\
\hline \multirow{3}{*}{$\begin{array}{l}\text { Ballast } \\
\text { bonding } \\
\text { technology }\end{array}$} & 5 & 0,646 & 0,770 & 0,274 & 0,599 & 0,777 & 0,186 \\
\hline & 40 & 0,746 & 0,867 & 0,354 & 0,573 & 0,703 & 0,208 \\
\hline & 60 & 0,804 & 0,948 & 0,471 & 0,547 & 0,663 & 0,259 \\
\hline \multirow[t]{3}{*}{ Safety caps } & 5 & 0,669 & 1,043 & 0,462 & 0,685 & 0,884 & 0,201 \\
\hline & 40 & 0,778 & 1,179 & 0,569 & 0,657 & 0,793 & 0,221 \\
\hline & 60 & 0,827 & 1,210 & 0,694 & 0,624 & 0,750 & 0,269 \\
\hline
\end{tabular}


bonding and they were $0,6-0,9 \mathrm{~mm}$ in the track section fixed with safety caps.

- The subsidence of the outside rail were similar in the two track sections at all three speeds.

The relative lateral horizontal displacements of the head on the outside rail:

- The relative lateral horizontal displacements of the outside rail compared to the sleeper were $0,2-0,3 \mathrm{~mm}$ in the track section stabilized by ballast bonding and they were also $0,2-$ $0,3 \mathrm{~mm}$ in the track section fixed with safety caps.

- The relative lateral horizontal displacements of the outside rail were similar in the two track sections at all three speeds.

\subsubsection{Comparison of the results of the track section stabi-} lized by ballast bonding and of the track section built with $Y$ steel sleepers

The final results of the track section stabilized by ballast bonding and of the track section built with Y steel sleepers are summarized in Table 8. The comparison of the results in bar graph format is shown for the speed $5 \mathrm{~km} / \mathrm{h}$ in Fig. 5 for the speed $40 \mathrm{~km} / \mathrm{h}$ in Fig. 6 and for the speed $60 \mathrm{~km} / \mathrm{h}$ in Fig. 7

On the basis of the measurement results of the track section stabilized by ballast bonding and of the track section built with Y steel sleepers, the main statements are the follows:

The absolute vertical displacements of the sleepers:

- The subsidence of the sleepers in the ballast bed were 0,6 $1,0 \mathrm{~mm}$ in the track section stabilized by ballast bonding and they were $1,4-1,9 \mathrm{~mm}$ in the track section built with $\mathrm{Y}$ steel sleepers.

- The subsidence of the sleepers were bigger on the inside than on the outside in both track sections at all three speeds.

- On the both sides the subsidence of the sleepers were smaller in the track section stabilized by ballast bonding than in the track section built with Y steel sleepers at all three speeds.

The absolute lateral horizontal displacements of the sleepers:

- The lateral horizontal displacements of the sleepers in the ballast bed were $0,3-0,5 \mathrm{~mm}$ in the track section stabilized by ballast bonding and they were $0,1-0,3 \mathrm{~mm}$ in the track section built with Y steel sleepers.

- The lateral horizontal displacements of the sleepers were bigger in the track section stabilized by ballast bonding than in the track section built with Y steel sleepers at all three speeds. This means that the lateral resistance of the track section stabilized by ballast bonding is smaller than the lateral resistance of the track section built with Y steel sleepers.

The relative vertical displacements of the flange on the outside rail:

- The subsidence of the outside rail compared to the sleeper were $0,5-0,8 \mathrm{~mm}$ in the track section stabilized by ballast bonding and they were $0,1-0,7 \mathrm{~mm}$ in the track section built with Y steel sleepers.

- The subsidence of the outside rail were bigger in the track section stabilized by ballast bonding than in the track section built with Y steel sleepers at all three speeds.

The relative lateral horizontal displacements of the head on the outside rail:

- The relative lateral horizontal displacements of the outside rail compared to the sleeper were $0,2-0,3 \mathrm{~mm}$ in the track section stabilized by ballast bonding and they were $0,3-0,5$ $\mathrm{mm}$ in the track section built with Y steel sleepers.

- The relative lateral horizontal displacements of the outside rail were smaller in the track section stabilized by ballast bonding than in the track section built with Y steel sleepers at all three speeds.

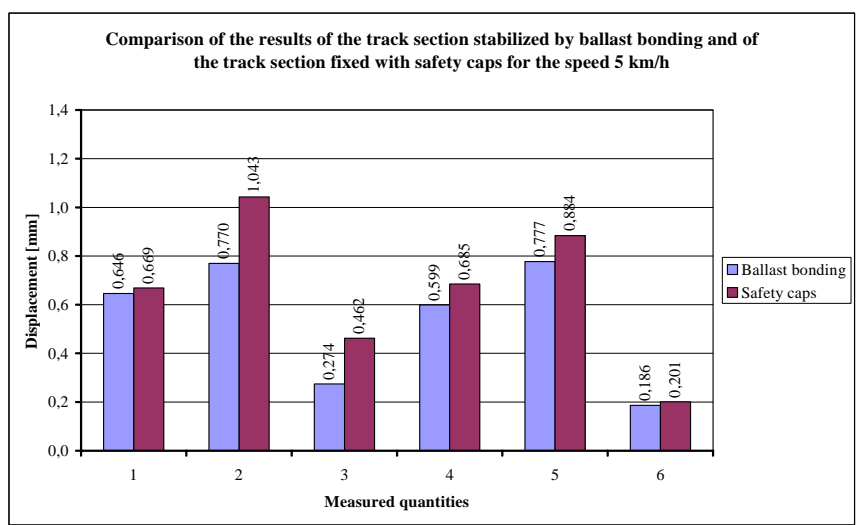

Fig. 2. Comparison of the results in bar graph format for the speed $5 \mathrm{~km} / \mathrm{h}$ (Note: 1 - absolute vertical displacement of the sleeper on the outside of the curve, 2 - absolute vertical displacement of the sleeper on the inside of the curve, 3 - absolute lateral horizontal displacement of the sleeper, 4 - relative vertical displacement of the inside flange of the outside rail, 5 - relative vertical displacement of the outside flange of the outside rail, 6 - relative lateral horizontal displacement of the head of the outside rail.)

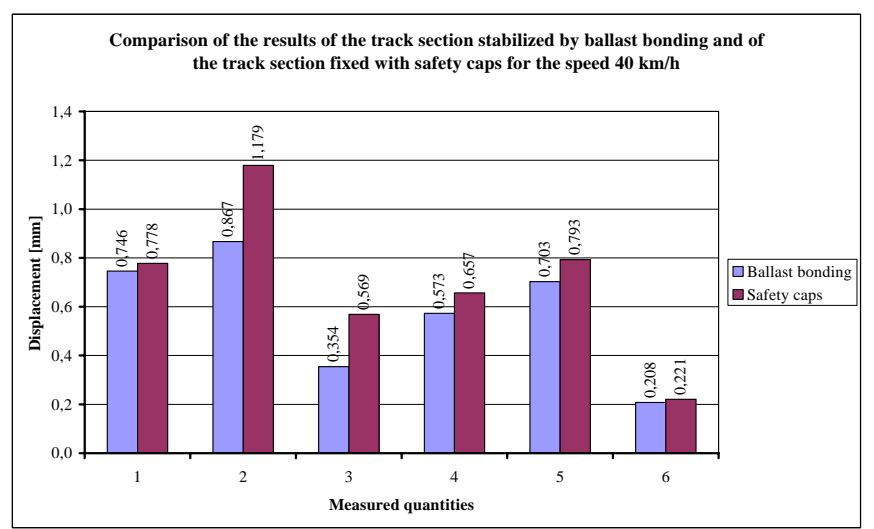

Fig. 3. Comparison of the results in bar graph format for the speed $40 \mathrm{~km} / \mathrm{h}$ (Note: 1 - absolute vertical displacement of the sleeper on the outside of the curve, 2 - absolute vertical displacement of the sleeper on the inside of the curve, 3 - absolute lateral horizontal displacement of the sleeper, 4 - relative vertical displacement of the inside flange of the outside rail, 5 - relative vertical displacement of the outside flange of the outside rail, 6 - relative lateral horizontal displacement of the head of the outside rail.) 
Tab. 8. The final results of the track section stabilized by ballast bonding and of the track section built with Y steel sleepers

\begin{tabular}{|c|c|c|c|c|c|c|c|}
\hline \multirow[t]{2}{*}{ Technology } & \multirow[t]{2}{*}{ Speed $[\mathrm{km} / \mathrm{h}]$} & \multicolumn{2}{|c|}{$\begin{array}{c}\text { Absolute vertical displacement } \\
\text { of the sleeper [mm] }\end{array}$} & \multirow{2}{*}{$\begin{array}{c}\text { Absolute } \\
\text { lateral } \\
\text { horizontal } \\
\text { displacement } \\
\text { of the sleeper } \\
\text { [mm] }\end{array}$} & \multirow{2}{*}{$\begin{array}{c}\text { Relative } \\
\text { vertical } \\
\text { displacement } \\
\text { of the flange } \\
\text { (inside) }[\mathrm{mm}]\end{array}$} & \multirow{2}{*}{$\begin{array}{c}\text { Relative } \\
\text { vertical } \\
\text { displacement } \\
\text { of the flange } \\
\text { (outside) }[\mathrm{mm}]\end{array}$} & \multirow{2}{*}{$\begin{array}{c}\text { Relative } \\
\text { lateral } \\
\text { horizontal } \\
\text { displacement } \\
\text { of the head } \\
\text { [mm] }\end{array}$} \\
\hline & & $\begin{array}{l}\text { Outside of the } \\
\text { curve }\end{array}$ & $\begin{array}{l}\text { Inside of the } \\
\text { curve }\end{array}$ & & & & \\
\hline \multirow{3}{*}{$\begin{array}{c}\text { Ballast } \\
\text { bonding } \\
\text { technology }\end{array}$} & 5 & 0,646 & 0,770 & 0,274 & 0,599 & 0,777 & 0,186 \\
\hline & 40 & 0,746 & 0,867 & 0,354 & 0,573 & 0,703 & 0,208 \\
\hline & 60 & 0,804 & 0,948 & 0,471 & 0,547 & 0,663 & 0,259 \\
\hline \multirow[t]{3}{*}{$\begin{array}{l}\text { Y steel } \\
\text { sleepers }\end{array}$} & 5 & 1,449 & 1,621 & 0,127 & 0,198 & 0,715 & 0,446 \\
\hline & 40 & 1,652 & 1,841 & 0,207 & 0,038 & 0,476 & 0,338 \\
\hline & 60 & 1,600 & 1,764 & 0,250 & 0,099 & 0,474 & 0,336 \\
\hline
\end{tabular}

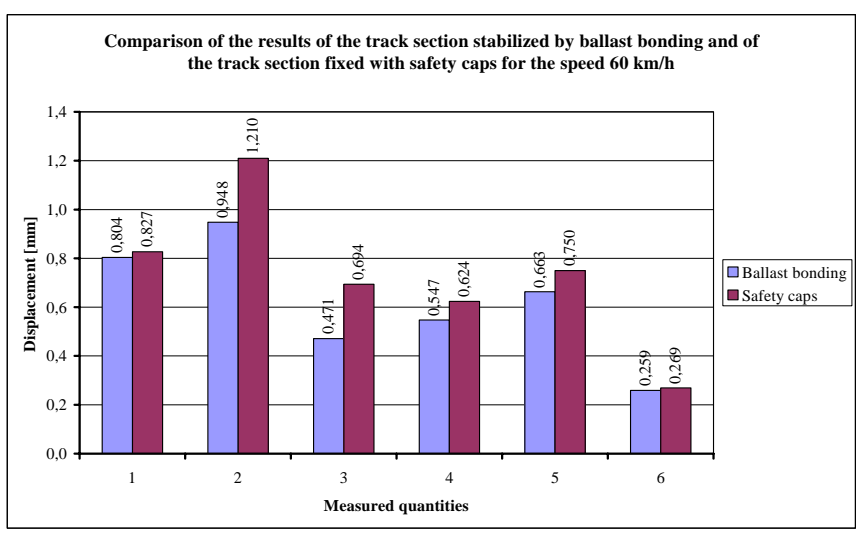

Fig. 4. Comparison of the results in bar graph format for the speed $60 \mathrm{~km} / \mathrm{h}$ (Note: 1 - absolute vertical displacement of the sleeper on the outside of the curve, 2 - absolute vertical displacement of the sleeper on the inside of the curve, 3 - absolute lateral horizontal displacement of the sleeper, 4 - relative vertical displacement of the inside flange of the outside rail, 5 - relative vertical displacement of the outside flange of the outside rail, 6 - relative lateral horizontal displacement of the head of the outside rail.)

\section{Examination of the geometric conditions of the tracks on the basis of measurement results of a track measuring car}

\subsection{The implementation of the measurements}

The track measurements were made by the FMK 004 track measuring car which type was Plasser EM 120. The track measuring car measured and registered the alignments of the two rails, the levels of the two rails, the gauge and calculated the SAD qualification number with the following formula:

$$
\begin{aligned}
S A D= & \frac{1}{3}\left(S I K T_{2,5}+S I K T_{6,0}\right. \\
& \left.+\frac{I R_{\text {left }}+I R_{\text {right }}}{2}+\frac{S P P_{\text {left }}+S P P_{\text {right }}}{2}\right),
\end{aligned}
$$

where:

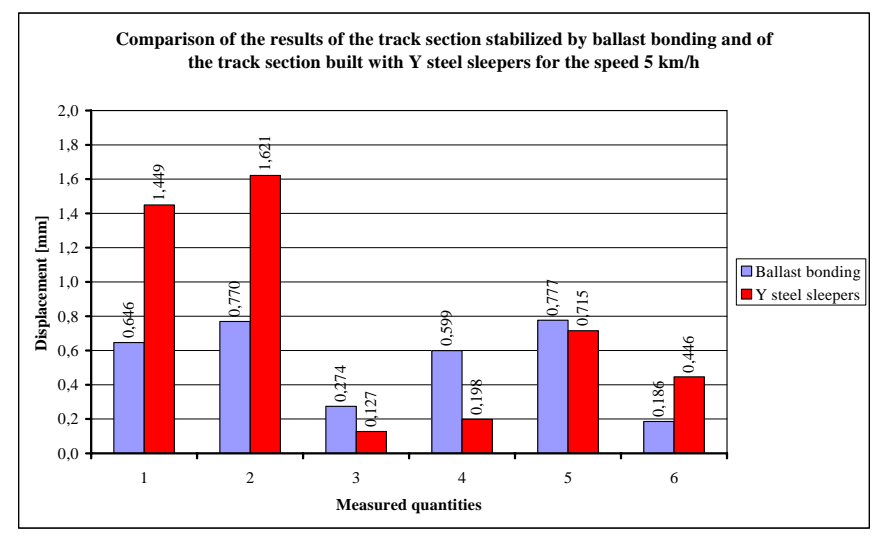

Fig. 5. Comparison of the results in bar graph format for the speed $5 \mathrm{~km} / \mathrm{h}$ (Note: 1 - absolute vertical displacement of the sleeper on the outside of the curve, 2 - absolute vertical displacement of the sleeper on the inside of the curve, 3 - absolute lateral horizontal displacement of the sleeper, 4 - relative vertical displacement of the inside flange of the outside rail, 5 - relative vertical displacement of the outside flange of the outside rail, 6 - relative lateral horizontal displacement of the head of the outside rail.)

- $S A D$ is the qualification number,

- $S I K T_{2,5}$ is the twist measured on $2,5 \mathrm{~m}$ base length,

- $S I K T_{6,0}$ is the twist measured on $6,0 \mathrm{~m}$ base length,

- $I R_{\text {left }}$ is the alignment on the left rail,

- $I R_{\text {right }}$ is the alignment on the right rail,

- $S P P_{\text {left }}$ is the level on the left rail,

- $S P P_{\text {right }}$ is the level on the right rail.

The track measurements were made at the following places:

- The track section stabilized by ballast bonding: between sections $948+60-953+40$.

- The track section fixed with safety caps: between sections $451+80-453+40$.

The evaluations of the measurement results were made as the follows: 


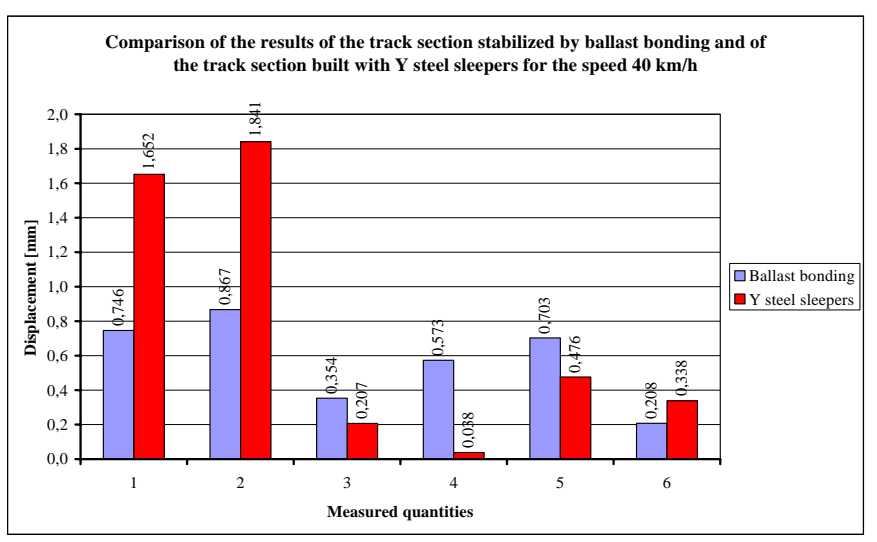

Fig. 6. Comparison of the results in bar graph format for the speed $40 \mathrm{~km} / \mathrm{h}$ (Note: 1 - absolute vertical displacement of the sleeper on the outside of the curve, 2 - absolute vertical displacement of the sleeper on the inside of the curve, 3 - absolute lateral horizontal displacement of the sleeper, 4 - relative vertical displacement of the inside flange of the outside rail, 5 - relative vertical displacement of the outside flange of the outside rail, 6 - relative lateral horizontal displacement of the head of the outside rail.)

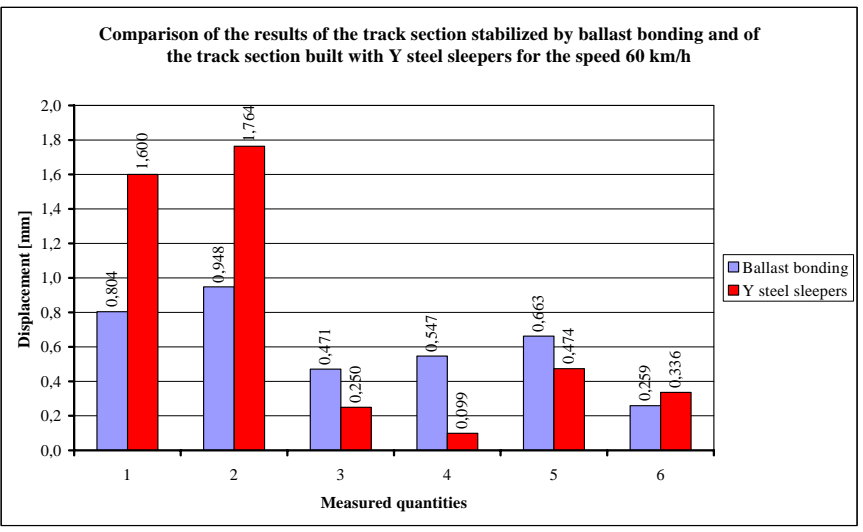

Fig. 7. Comparison of the results in bar graph format for the speed $60 \mathrm{~km} / \mathrm{h}$ (Note: 1 - absolute vertical displacement of the sleeper on the outside of the curve, 2 - absolute vertical displacement of the sleeper on the inside of the curve, 3 - absolute lateral horizontal displacement of the sleeper, 4 - relative vertical displacement of the inside flange of the outside rail, 5 - relative vertical displacement of the outside flange of the outside rail, 6 - relative lateral horizontal displacement of the head of the outside rail.)

- The $S A D$ qualification numbers - based on territorial principle.

- The alignment errors - based on territorial principle.

- The gauge errors - based on principle from base line to top.

- The level errors - based on principle from base line to top.

\subsection{The results of the measurements and the comparison of the results}

The $S A D$ qualification numbers evaluated according to territorial principle are summarized for the track section stabilized by ballast bonding in Table 9 for the track section fixed with safety caps in Table 10 The comparison of the values converted to $500 \mathrm{~m}$ length is shown in Fig. 8. The conversion to $500 \mathrm{~m}$ length was made with the following method: the amounts were divided by the length of the track sections (the length of the track section stabilized by ballast bonding was $480 \mathrm{~m}$ and the length of the track section fixed with safety caps was $160 \mathrm{~m}$ ) and were multiplied by the conversion length $(500 \mathrm{~m})$.

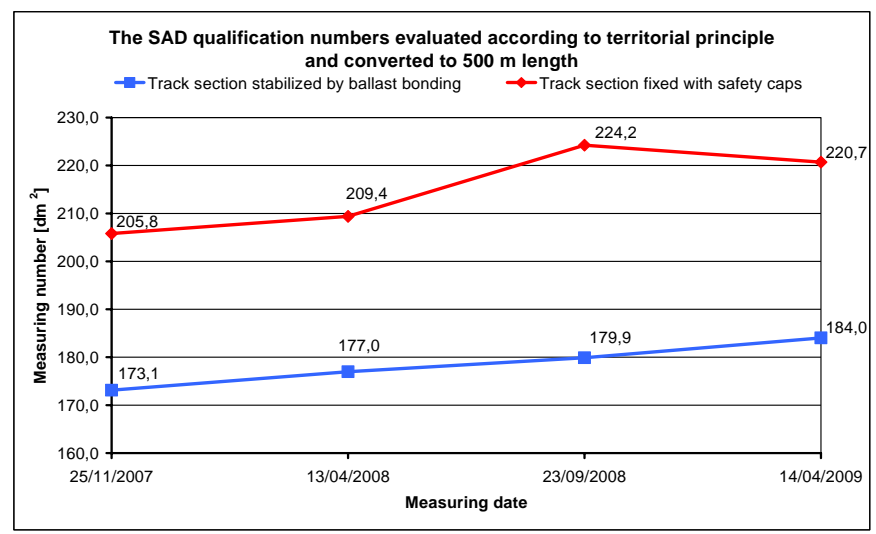

Fig. 8. Comparison of the $S A D$ values converted to $500 \mathrm{~m}$ length

The alignment errors evaluated according to territorial principle are summarized for the track section stabilized by ballast bonding in Table 11 for the track section fixed with safety caps in Table 12 The comparison of the values converted to $500 \mathrm{~m}$ length is shown in Fig. 9. The conversion to $500 \mathrm{~m}$ length was made with the same method: the amounts were divided by the length of the track sections and were multiplied by the conversion length $(500 \mathrm{~m})$.

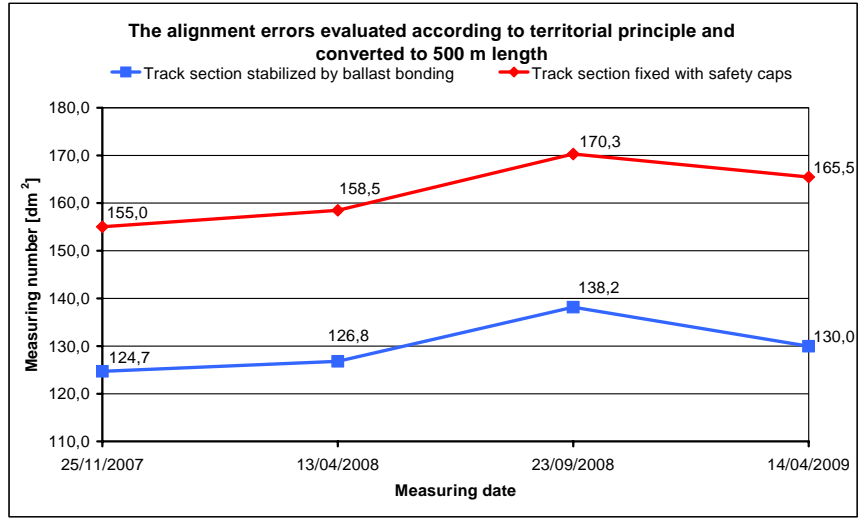

Fig. 9. Comparison of the alignment error values converted to $500 \mathrm{~m}$ length

The gauge errors evaluated according to principle from base line to top are summarized for the track section stabilized by ballast bonding in Table 13 for the track section fixed with safety caps in Table 14 The comparison of the average values is shown in Fig. 10 and the comparison of the maximal values is shown in Fig. 11 .

The level errors evaluated according to principle from base line to top are summarized for the track section stabilized by ballast bonding in Table 15 for the track section fixed with safety caps in Table 16 The comparison of the average values is shown in Fig. 12 and the comparison of the maximal values is shown in Fig. 13 
Tab. 9. The $S A D$ qualification numbers evaluated according to territorial principle for the track section stabilized by ballast bonding

\begin{tabular}{|c|c|c|c|c|c|}
\hline & \multirow[t]{2}{*}{ Last } & \multicolumn{4}{|c|}{$\begin{array}{l}\text { The SAD qualification numbers evaluated according to territorial principle } \\
\text { for the track section stabilized by ballast bonding }\end{array}$} \\
\hline & & $25 / 11 / 2007$ & $13 / 04 / 2008$ & $23 / 09 / 2008$ & $14 / 04 / 2009$ \\
\hline $948+60$ & $948+80$ & 7,0 & 8,0 & 4,4 & 8,9 \\
\hline $948+80$ & $949+00$ & 4,7 & 5,2 & 5,9 & 7,1 \\
\hline $949+00$ & $949+20$ & 6,4 & 5,8 & 7,2 & 5,4 \\
\hline $949+20$ & $949+40$ & 6,2 & 5,8 & 11,6 & 5,8 \\
\hline $949+40$ & $949+60$ & 10,5 & 9,2 & 8,8 & 6,8 \\
\hline $949+60$ & $949+80$ & 8,8 & 10,4 & 8,6 & 11,3 \\
\hline $949+80$ & $950+00$ & 9,3 & 8,2 & 7,6 & 9,9 \\
\hline $950+00$ & $950+20$ & 8,3 & 9,2 & 5,8 & 8,3 \\
\hline $950+20$ & $950+40$ & 5,9 & 7,0 & 6,4 & 8,4 \\
\hline $950+40$ & $950+60$ & 5,8 & 6,4 & 7,0 & 5,3 \\
\hline $950+60$ & $950+80$ & 6,8 & 6,4 & 4,2 & 6,7 \\
\hline $950+80$ & $951+00$ & 5,1 & 6,7 & 6,8 & 6,7 \\
\hline $951+00$ & $951+20$ & 6,5 & 6,6 & 7,9 & 4,6 \\
\hline $951+20$ & $951+40$ & 7,4 & 6,7 & 9,9 & 6,9 \\
\hline $951+40$ & $951+60$ & 8,7 & 7,3 & 6,7 & 7,5 \\
\hline $951+60$ & $951+80$ & 6,6 & 7,2 & 7,2 & 9,2 \\
\hline $951+80$ & $952+00$ & 6,8 & 7,9 & 5,3 & 8,1 \\
\hline $952+00$ & $952+20$ & 4,8 & 5,4 & 6,8 & 7,9 \\
\hline $952+20$ & $952+40$ & 6,6 & 5,0 & 6,1 & 5,6 \\
\hline $952+40$ & $952+60$ & 4,9 & 7,1 & 8,0 & 6,5 \\
\hline $952+60$ & $952+80$ & 7,7 & 7,9 & 8,7 & 6,7 \\
\hline $952+80$ & $953+00$ & 8,7 & 6,9 & 5,5 & 8,5 \\
\hline $953+00$ & $953+20$ & 5,6 & 7,5 & 6,9 & 7,7 \\
\hline $953+20$ & $953+40$ & 7,1 & 6,1 & 9,3 & 6,9 \\
\hline \multicolumn{2}{|c|}{$948+60-953+40$ amount } & 166,2 & 169,9 & 172,7 & 176,7 \\
\hline \multicolumn{2}{|c|}{$\begin{array}{l}948+60-953+40 \text { amount } \\
\text { converted to } 500 \mathrm{~m} \text { length }\end{array}$} & 173,1 & 177,0 & 179,9 & 184,0 \\
\hline \multicolumn{2}{|c|}{ „C” limit } & & eed $60 \mathrm{~km} / \mathrm{h}$, & sly welded rai & \\
\hline
\end{tabular}

Tab. 10. The $S A D$ qualification numbers evaluated according to territorial principle for the track section fixed with safety caps

\begin{tabular}{cccccc}
\hline \multirow{2}{*}{ First } & Last & \multicolumn{2}{c}{ The $S A D$ qualification numbers evaluated according to territorial principle } \\
for the track section fixed with safety caps
\end{tabular}

4.3 Analysis of the results, statements

On the basis of the track measurement results of the track section stabilized by ballast bonding and of the track section fixed with safety caps, the main statements are the follows: The
$S A D$ qualification number:

The $S A D$ qualification number: The SAD qualification number was smaller in the track section stabilized by ballast bonding than in the track section fixed with safety caps in 
Tab. 11. The alignment errors evaluated according to territorial principle for the track section stabilized by ballast bonding

\begin{tabular}{|c|c|c|c|c|c|}
\hline \multirow[t]{2}{*}{ First } & \multirow[t]{2}{*}{ Last } & \multicolumn{4}{|c|}{$\begin{array}{l}\text { The alignment errors evaluated according to territorial principle } \\
\text { for the track section stabilized by ballast bonding }\end{array}$} \\
\hline & & $25 / 11 / 2007$ & $13 / 04 / 2008$ & 23/09/2008 & $14 / 04 / 2009$ \\
\hline $948+60$ & $948+80$ & 4,7 & 5,8 & 3,5 & 7,4 \\
\hline $948+80$ & $949+00$ & 3,3 & 3,6 & 3,8 & 6,0 \\
\hline $949+00$ & $949+20$ & 4,0 & 3,7 & 4,3 & 3,7 \\
\hline $949+20$ & $949+40$ & 3,4 & 3,4 & 3,6 & 3,6 \\
\hline $949+40$ & $949+60$ & 3,6 & 5,0 & 4,9 & 3,9 \\
\hline $949+60$ & $949+80$ & 4,1 & 3,9 & 5,9 & 3,7 \\
\hline $949+80$ & $950+00$ & 5,6 & 4,5 & 5,2 & 5,2 \\
\hline $950+00$ & $950+20$ & 4,6 & 5,5 & 5,7 & 4,7 \\
\hline $950+20$ & $950+40$ & 5,3 & 5,5 & 7,0 & 5,6 \\
\hline $950+40$ & $950+60$ & 5,5 & 5,7 & 9,1 & 5,1 \\
\hline $950+60$ & $950+80$ & 8,1 & 7,2 & 4,2 & 6,5 \\
\hline $950+80$ & $951+00$ & 4,9 & 6,8 & 5,5 & 8,4 \\
\hline $951+00$ & $951+20$ & 5,8 & 5,9 & 7,4 & 4,5 \\
\hline $951+20$ & $951+40$ & 6,3 & 5,5 & 6,6 & 5,4 \\
\hline $951+40$ & $951+60$ & 5,1 & 6,5 & 3,7 & 6,6 \\
\hline $951+60$ & $951+80$ & 3,0 & 3,0 & 4,2 & 6,4 \\
\hline $951+80$ & $952+00$ & 4,4 & 4,0 & 3,9 & 3,9 \\
\hline $952+00$ & $952+20$ & 3,0 & 2,6 & 4,5 & 4,3 \\
\hline $952+20$ & $952+40$ & 4,5 & 2,9 & 5,6 & 3,1 \\
\hline $952+40$ & $952+60$ & 4,7 & 5,7 & 6,6 & 4,2 \\
\hline $952+60$ & $952+80$ & 5,0 & 5,5 & 6,2 & 6,2 \\
\hline $952+80$ & $953+00$ & 5,7 & 5,7 & 5,3 & 6,0 \\
\hline $953+00$ & $953+20$ & 5,4 & 5,7 & 9,0 & 5,5 \\
\hline $953+20$ & $953+40$ & 9,6 & 7,9 & 6,9 & 4,8 \\
\hline \multicolumn{2}{|c|}{$948+60-953+40$ amount } & 119,7 & 121,7 & 132,7 & 124,8 \\
\hline \multicolumn{2}{|c|}{$948+60-953+40$ amount } & 124,7 & 126,8 & 138,2 & 130,0 \\
\hline
\end{tabular}

Tab. 12. The alignment errors evaluated according to territorial principle for the track section fixed with safety caps

\begin{tabular}{|c|c|c|c|c|c|}
\hline \multirow[t]{2}{*}{ First } & \multirow[t]{2}{*}{ Last } & \multicolumn{4}{|c|}{$\begin{array}{l}\text { The alignment errors evaluated according to territorial principle } \\
\text { for the track section fixed with safety caps }\end{array}$} \\
\hline & & $25 / 11 / 2007$ & $13 / 04 / 2008$ & 23/09/2008 & $14 / 04 / 2009$ \\
\hline $451+80$ & $452+00$ & 9,0 & 7,2 & 7,2 & 9,2 \\
\hline $452+00$ & $452+20$ & 4,6 & 4,3 & 5,1 & 5,2 \\
\hline $452+20$ & $452+40$ & 6,1 & 6,8 & 8,1 & 6,9 \\
\hline $452+40$ & $452+60$ & 6,8 & 8,3 & 9,2 & 7,2 \\
\hline $452+60$ & $452+80$ & 7,4 & 8,0 & 7,9 & 8,6 \\
\hline $452+80$ & $453+00$ & 6,9 & 4,9 & 4,8 & 6,9 \\
\hline $453+00$ & $453+20$ & 3,8 & 4,1 & 4,7 & 4,2 \\
\hline $453+20$ & $453+40$ & 5,0 & 7,2 & 7,4 & 4,7 \\
\hline \multicolumn{2}{|c|}{$451+80-453+40$ amount } & 49,6 & 50,7 & 54,5 & 53,0 \\
\hline $451+80-453+40$ amount & Imount & 155,0 & 158,5 & 170,3 & 165,5 \\
\hline
\end{tabular}

all four measurement periods. During the whole test period (between the first and last measurement periods) the change of $S A D$ qualification number was 10,9 in the track section stabilized by ballast bonding $\left(\triangle S A D^{\text {ballast bonding }}=10,9\right)$ and it was 14,9 in the track section fixed with safety caps $\left(\triangle S A D^{\text {safety caps }}=14,9\right)$. This means that the rate of change of SAD qualification number was smaller in the track section stabilized by ballast bonding than in the track section fixed with safety caps, so during the same time (test period) the degradation process was slower in the track section stabilized by ballast bonding than in the track section fixed with safety caps. It follows that the geometric conditions of the track section stabilized by ballast bonding were better than the geometric conditions of the track section fixed with safety caps. 
Tab. 13. The gauge errors evaluated according to principle from base line to top for the track section stabilized by ballast bonding

\begin{tabular}{|c|c|c|c|c|c|}
\hline & \multirow[t]{2}{*}{ Last } & \multicolumn{4}{|c|}{$\begin{array}{l}\text { The gauge errors evaluated according to principle from base line to top } \\
\text { for the track section stabilized by ballast bonding }\end{array}$} \\
\hline & & $25 / 11 / 2007$ & $13 / 04 / 2008$ & $23 / 09 / 2008$ & $14 / 04 / 2009$ \\
\hline $948+60$ & $948+80$ & 8,5 & 8,0 & 7,8 & 8,0 \\
\hline $948+80$ & $949+00$ & 8,8 & 8,8 & 9,3 & 9,5 \\
\hline $949+00$ & $949+20$ & 10,6 & 8,3 & 9,9 & 10,6 \\
\hline $949+20$ & $949+40$ & 10,2 & 10,6 & 9,1 & 12,1 \\
\hline $949+40$ & $949+60$ & 10,5 & 10,2 & 8,7 & 12,4 \\
\hline $949+60$ & $949+80$ & 9,8 & 10,0 & 9,0 & 11,6 \\
\hline $949+80$ & $950+00$ & 10,0 & 9,8 & 8,7 & 12,0 \\
\hline $950+00$ & $950+20$ & 9,3 & 10,1 & 8,5 & 12,1 \\
\hline $950+20$ & $950+40$ & 9,8 & 9,3 & 9,4 & 11,5 \\
\hline $950+40$ & $950+60$ & 9,7 & 9,9 & 7,4 & 11,1 \\
\hline $950+60$ & $950+80$ & 7,4 & 7,6 & 8,8 & 11,8 \\
\hline $950+80$ & $951+00$ & 9,4 & 10,1 & 8,7 & 9,2 \\
\hline $951+00$ & $951+20$ & 9,5 & 9,5 & 7,6 & 10,4 \\
\hline $951+20$ & $951+40$ & 8,7 & 8,3 & 10,0 & 11,5 \\
\hline $951+40$ & $951+60$ & 11,2 & 9,4 & 10,6 & 9,9 \\
\hline $951+60$ & $951+80$ & 11,6 & 11,4 & 9,1 & 12,1 \\
\hline $951+80$ & $952+00$ & 9,5 & 11,0 & 8,4 & 13,2 \\
\hline $952+00$ & $952+20$ & 9,0 & 8,2 & 10,5 & 11,8 \\
\hline $952+20$ & $952+40$ & 12,2 & 10,8 & 9,4 & 11,0 \\
\hline $952+40$ & $952+60$ & 10,2 & 11,6 & 9,7 & 13,5 \\
\hline $952+60$ & $952+80$ & 11,0 & 10,6 & 11,8 & 12,5 \\
\hline $952+80$ & $953+00$ & 12,0 & 12,5 & 6,3 & 11,9 \\
\hline $953+00$ & $953+20$ & 6,5 & 10,9 & 4,8 & 14,7 \\
\hline $953+20$ & $953+40$ & 5,5 & 7,9 & 7,8 & 9,1 \\
\hline \multicolumn{2}{|c|}{ Average values } & 9,6 & 9,8 & 8,8 & 11,4 \\
\hline \multicolumn{2}{|c|}{ Maximal values } & 12,2 & 12,5 & 11,8 & 14,7 \\
\hline \multicolumn{2}{|c|}{ „C” limit } & \multicolumn{4}{|c|}{30 (at speed $60 \mathrm{~km} / \mathrm{h}$ ) } \\
\hline
\end{tabular}

Tab. 14. The gauge errors evaluated according to principle from base line to top for the track section fixed with safety caps

\begin{tabular}{cccccc}
\hline \multirow{2}{*}{ First } & Last & \multicolumn{2}{c}{ The gauge errors evaluated according to principle from base line to top } \\
for the track section fixed with safety caps
\end{tabular}

The alignment error: The alignment error was smaller in the track section stabilized by ballast bonding than in the track section fixed with safety caps in all four measurement periods. During the whole test period (between the first and last measurement periods) the change of alignment error was 5,3 in the track section stabilized by ballast bonding ( $\Delta I R^{\text {ballast bonding }}=5,3$ ) and it was 10,5 in the track section fixed with safety caps $\left(\Delta I R^{\text {safety caps }}=10,5\right)$. This means that the rate of change of alignment error was smaller in the track section stabilized by ballast bonding than in the 
Tab. 15. The level errors evaluated according to principle from base line to top for the track section stabilized by ballast bonding

\begin{tabular}{|c|c|c|c|c|c|c|c|c|c|}
\hline & \multirow[t]{3}{*}{ Last } & \multicolumn{7}{|c|}{$\begin{array}{l}\text { The surface errors evaluated according to principle from base line to top } \\
\text { for the track section stabilized by ballast bonding }\end{array}$} & \\
\hline & & \multicolumn{2}{|c|}{$25 / 11 / 2007$} & \multicolumn{2}{|c|}{$13 / 04 / 2008$} & \multicolumn{2}{|c|}{$23 / 09 / 2008$} & \multicolumn{2}{|c|}{$14 / 04 / 2009$} \\
\hline & & left rail & right rail & left rail & right rail & left rail & right rail & left rail & right rail \\
\hline $948+60$ & $948+80$ & 5,1 & 4,1 & 3,7 & 5,7 & 4,1 & 3,0 & 3,1 & 7,4 \\
\hline $948+80$ & $949+00$ & 4,2 & 3,5 & 4,4 & 5,2 & 3,4 & 6,7 & 4,7 & 4,9 \\
\hline $949+00$ & $949+20$ & 3,5 & 6,2 & 3,6 & 4,2 & 5,2 & 4,7 & 3,6 & 4,4 \\
\hline $949+20$ & $949+40$ & 4,1 & 6,7 & 4,2 & 6,9 & 7,1 & 12,0 & 3,1 & 3,9 \\
\hline $949+40$ & $949+60$ & 8,3 & 9,4 & 6,5 & 8,1 & 6,3 & 7,0 & 5,6 & 5,9 \\
\hline $949+60$ & $949+80$ & 7,4 & 7,3 & 6,4 & 11,4 & 7,8 & 6,2 & 9,5 & 12,1 \\
\hline $949+80$ & $950+00$ & 8,9 & 5,9 & 8,1 & 5,7 & 9,5 & 6,2 & 4,6 & 11,0 \\
\hline $950+00$ & $950+20$ & 11,7 & 7,2 & 11,5 & 6,6 & 3,9 & 3,5 & 7,8 & 6,1 \\
\hline $950+20$ & $950+40$ & 4,9 & 3,5 & 11,0 & 5,9 & 4,9 & 5,1 & 9,6 & 6,6 \\
\hline $950+40$ & $950+60$ & 3,5 & 4,0 & 5,1 & 4,8 & 4,9 & 3,4 & 3,7 & 3,6 \\
\hline $950+60$ & $950+80$ & 6,0 & 2,9 & 5,1 & 4,2 & 2,7 & 3,6 & 5,3 & 5,0 \\
\hline $950+80$ & $951+00$ & 3,1 & 4,5 & 5,1 & 4,0 & 3,6 & 4,9 & 6,0 & 3,4 \\
\hline $951+00$ & $951+20$ & 3,6 & 4,6 & 4,1 & 5,0 & 5,6 & 5,6 & 4,5 & 3,1 \\
\hline $951+20$ & $951+40$ & 5,1 & 5,7 & 5,4 & 5,4 & 7,6 & 10,2 & 3,3 & 4,9 \\
\hline $951+40$ & $951+60$ & 6,7 & 8,7 & 4,3 & 8,1 & 4,6 & 6,7 & 6,2 & 6,7 \\
\hline $951+60$ & $951+80$ & 6,1 & 8,3 & 7,0 & 10,3 & 6,0 & 5,5 & 7,9 & 8,2 \\
\hline $951+80$ & $952+00$ & 4,3 & 4,4 & 5,8 & 6,0 & 4,4 & 5,5 & 7,8 & 9,6 \\
\hline $952+00$ & $952+20$ & 4,4 & 5,2 & 4,3 & 5,4 & 5,0 & 8,0 & 4,9 & 5,7 \\
\hline $952+20$ & $952+40$ & 5,6 & 7,5 & 3,4 & 4,8 & 6,2 & 6,4 & 5,0 & 6,2 \\
\hline $952+40$ & $952+60$ & 6,2 & 5,1 & 6,1 & 8,1 & 7,4 & 8,0 & 3,8 & 8,0 \\
\hline $952+60$ & $952+80$ & 5,9 & 7,6 & 7,2 & 7,7 & 8,3 & 8,5 & 7,5 & 6,5 \\
\hline $952+80$ & $953+00$ & 9,4 & 8,0 & 5,6 & 9,0 & 4,8 & 3,5 & 7,0 & 8,1 \\
\hline $953+00$ & $953+20$ & 7,5 & 5,8 & 8,5 & 7,9 & 3,9 & 4,5 & 6,1 & 7,1 \\
\hline $953+20$ & $953+40$ & 3,6 & 3,0 & 4,5 & 2,9 & 5,2 & 8,4 & 9,4 & 7,9 \\
\hline \multicolumn{2}{|c|}{ Average values } & 5,8 & 5,8 & 5,9 & 6,4 & 5,5 & 6,1 & 5,8 & 6,5 \\
\hline \multicolumn{2}{|c|}{ Maximal values } & 11,7 & 9,4 & 11,5 & 11,4 & 9,5 & 12,0 & 9,6 & 12,1 \\
\hline \multicolumn{2}{|c|}{ „C" limit } & \multicolumn{6}{|c|}{24 (at speed $60 \mathrm{~km} / \mathrm{h}$ ) } & & \\
\hline
\end{tabular}

Tab. 16. The level errors evaluated according to principle from base line to top for the track section fixed with safety caps

\begin{tabular}{|c|c|c|c|c|c|c|c|c|c|}
\hline \multirow[t]{3}{*}{ First } & \multirow{2}{*}{$\begin{array}{l}\text { Last } \\
\text { ion }\end{array}$} & \multicolumn{7}{|c|}{$\begin{array}{l}\text { The surface errors evaluated according to principle from base line to top } \\
\text { for the track section fixed with safety caps }\end{array}$} & \\
\hline & & \multicolumn{2}{|c|}{$25 / 11 / 2007$} & \multicolumn{2}{|c|}{$13 / 04 / 2008$} & \multicolumn{2}{|c|}{$23 / 09 / 2008$} & \multicolumn{2}{|c|}{$14 / 04 / 2009$} \\
\hline & Section & left rail & right rail & left rail & right rail & left rail & right rail & left rail & right rail \\
\hline $451+80$ & $452+00$ & 6,3 & 5,6 & 6,3 & 6,1 & 6,0 & 6,6 & 8,2 & 5,7 \\
\hline $452+00$ & $452+20$ & 5,3 & 5,0 & 3,8 & 6,6 & 3,7 & 6,6 & 5,5 & 5,2 \\
\hline $452+20$ & $452+40$ & 3,4 & 7,1 & 3,4 & 6,2 & 3,5 & 6,0 & 3,7 & 7,5 \\
\hline $452+40$ & $452+60$ & 3,1 & 7,6 & 4,2 & 7,9 & 4,4 & 7,3 & 3,8 & 8,3 \\
\hline $452+60$ & $452+80$ & 5,0 & 12,0 & 5,2 & 11,7 & 5,6 & 14,2 & 6,1 & 12,2 \\
\hline $452+80$ & $453+00$ & 4,2 & 11,7 & 5,7 & 6,4 & 6,4 & 6,2 & 5,3 & 11,9 \\
\hline $453+00$ & $453+20$ & 6,6 & 3,2 & 6,0 & 3,5 & 5,7 & 3,9 & 7,9 & 4,8 \\
\hline $453+20$ & $453+40$ & 3,5 & 3,0 & 3,2 & 3,7 & 3,6 & 3,8 & 4,5 & 3,4 \\
\hline \multicolumn{2}{|c|}{ Average values } & 4,7 & 6,9 & 4,7 & 6,5 & 4,9 & 6,8 & 5,6 & 7,4 \\
\hline \multicolumn{2}{|c|}{ Maximal values } & 6,6 & 12,0 & 6,3 & 11,7 & 6,4 & 14,2 & 8,2 & 12,2 \\
\hline \multicolumn{2}{|c|}{ „C” limit } & \multicolumn{6}{|c|}{24 (at speed $60 \mathrm{~km} / \mathrm{h}$ ) } & & \\
\hline
\end{tabular}

track section fixed with safety caps, so during the same time (test period) the degradation process was slower in the track section stabilized by ballast bonding than in the track section fixed with safety caps. It follows that the alignment keep- ing of the track section stabilized by ballast bonding was better than the alignment keeping of the track section fixed with safety caps. 


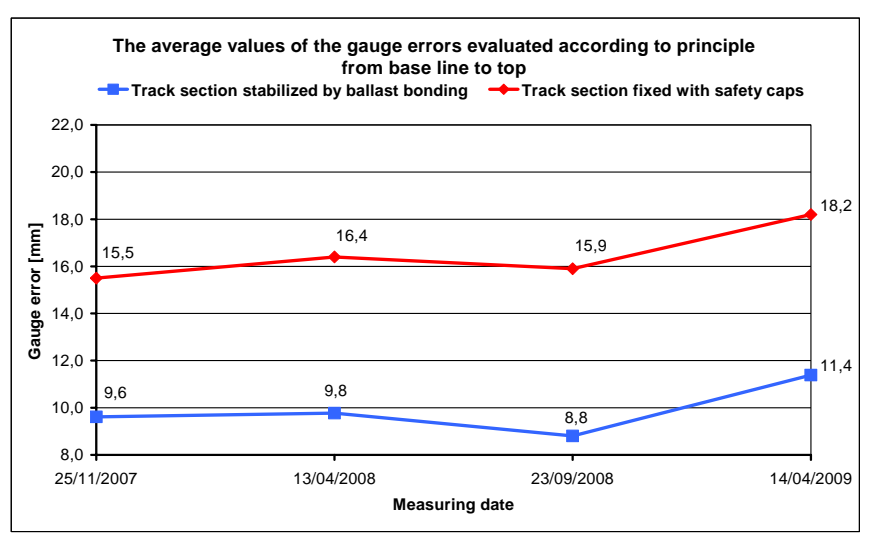

Fig. 10. Comparison of the average values of the gauge errors

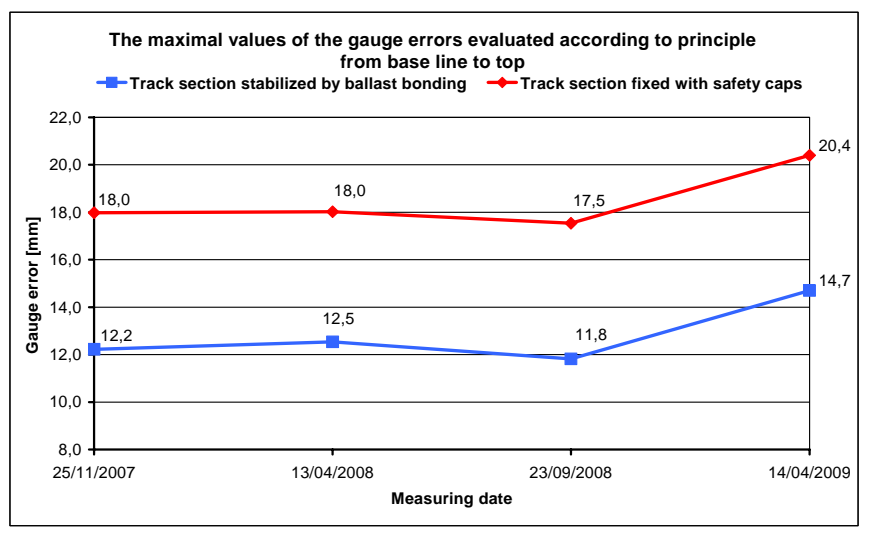

Fig. 11. Comparison of the maximal values of the gauge errors

The gauge error: The gauge error was smaller in the track section stabilized by ballast bonding than in the track section fixed with safety caps in all four measurement periods.

The level error: The level errors were in similar range in the two track sections in all four measurement periods.

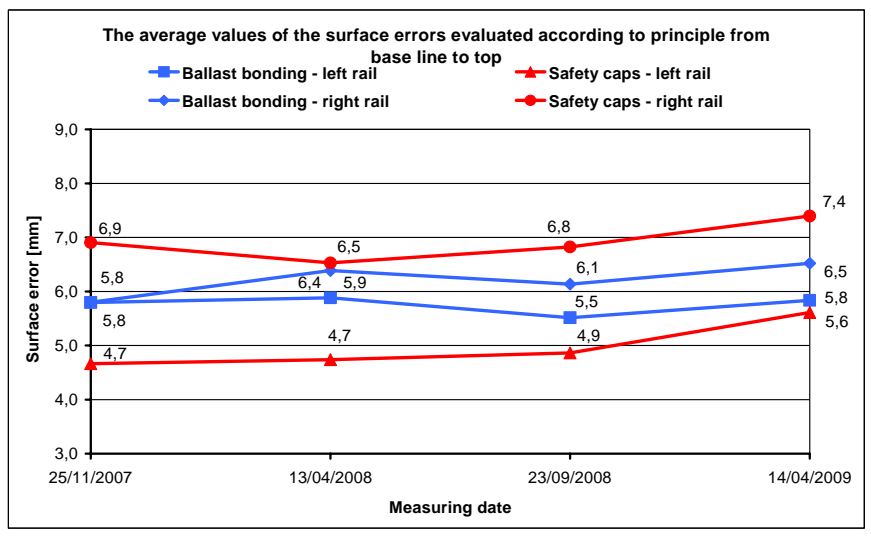

Fig. 12. Comparison of the average values of the level errors

\section{Conclusions}

On the basis of the tests and measurements in the track section stabilized by ballast bonding, in the track section fixed with safety caps and in the track section built with Y steel sleepers, the main statements are the follows:

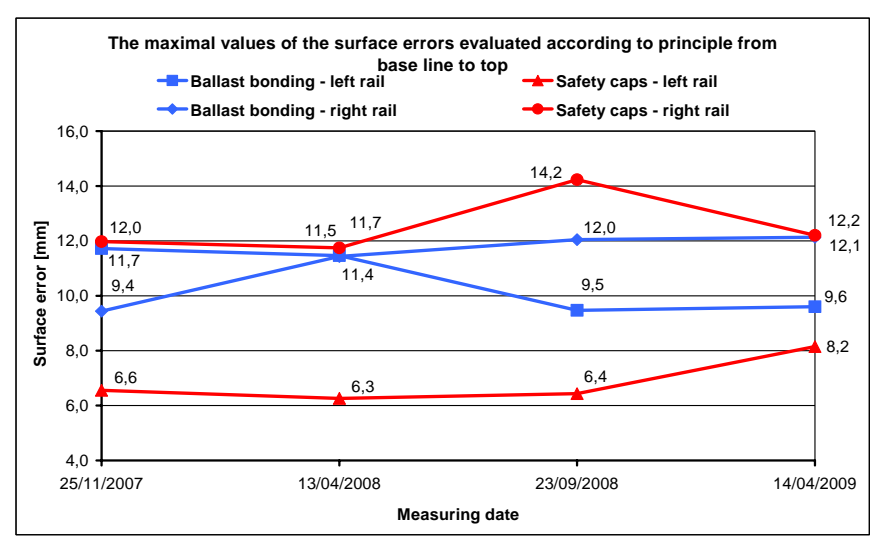

Fig. 13. Comparison of the maximal values of the level errors

- The lateral resistance of the continuously welded rail track with crushed stone ballast bed stabilized by ballast bonding technology (lateral structural bonding) is bigger than the lateral resistance of the continuously welded rail track with crushed stone ballast bed fixed with safety caps (to every sleeper).

- The lateral resistance of the continuously welded rail track with crushed stone ballast bed stabilized by ballast bonding technology (lateral structural bonding) is smaller than the lateral resistance of the continuously welded rail track with crushed stone ballast bed built with Y steel sleepers.

- The geometric conditions of the continuously welded rail track with crushed stone ballast bed stabilized by ballast bonding technology (lateral structural bonding) are better than the geometric conditions of the continuously welded rail track with crushed stone ballast bed fixed with safety caps (to every sleeper).

- The alignment keeping of the continuously welded rail track with crushed stone ballast bed stabilized by ballast bonding technology (lateral structural bonding) is better than the alignment keeping of the continuously welded rail track with crushed stone ballast bed fixed with safety caps (to every sleeper).

\section{References}

1 Kerr AD, An improved analysis for thermal track buckling, International Journal of Non-Linear Mechanics 15 (1980), no. 2, 99-114, DOI 10.1016/0020-7462(80)90004-9.

2 Tvergaard V, Needleman A, On localized thermal track buckling, International Journal of Mechanical Sciences 23 (1981), no. 10, 577-587, DOI 10.1016/0020-7403(81)90038-2.

3 Donley MG, Kerr AD, Thermal buckling of curved railroad tracks, International Journal of Non-Linear Mechanics 22 (1987), no. 3, 175-192, DOI 10.1016/0020-7462(87)90001-1.

4 Grissom GT, Kerr AD, Analysis of lateral track buckling using new frametype equations, International Journal of Mechanical Sciences 48 (January 2006), no. 1, 21-32, DOI 10.1016/j.ijmecsci.2005.09.006.

5 Wen-pei S, Ming-hsiang S, Cheng-I L, Germ GC, The critical loading for lateral buckling of continuous welded rail, Journal of Zhejiang University Science 6 (2005), no. 8, 878-885, DOI 10.1631/jzus.2005.A0878.

6 Lim NH, Park NH, Kang YJ, Stability of continuous welded rail track, 
Computers \& Structures 81 (September 2003), no. 22-23, 2219-2236, DOI 10.1016/S0045-7949(03)00287-6

7 Yaping W, Xu S, Wu C, Jianzhong S, Finite element analysis of stability of continuous welded rail with minor radius curve, 2010 International Conference on Artificial Intelligence and Computational Intelligence (Sanya, China, 2010), 2010, pp. 355-358, DOI 10.1109/AICI.2010.312.

8 Kabo E, A numerical study of the lateral ballast resistance in railway tracks, Proceedings of the Institution of Mechanical Engineers, Part F: Journal of Rail and Rapid Transit 220 (2006), no. 4, 425-433, DOI 10.1243/0954409JRRT61.

9 Koc W, Wilk A, Chrostowski P, Grulkowski S, Determination of the transverse resistance characteristics in railway track, Journal of Transportation Engineering 136 (2010), no. 12, 1057-1067, DOI 10.1061/(ASCE)TE.1943-5436.0000167.

10 Szabó J, Szabó J, Anwendungsmöglichkeiten für die Schotterverklebungstechnologie (Teil 1), Der Eisenbahn Ingenieur 2008 (June 2008), no. 6, 2025.

$11 \ldots$, Anwendungsmöglichkeiten für die Schotterverklebungstechnologie (Teil 2), Der Eisenbahn Ingenieur 2009 (June 2009), no. 6, 38-46.

12 Franz J, Bogenatmung und Gleislagestabilität des Y-Stahlschwellengleises in kleinen Halbmessern, Der Eisenbahn Ingenieur 2004 (December 2004), no. 12, 36-43.

13 Liegner N, Investigation of the internal forces of the first track constructed with Y-shape steel sleepers under operation in Hungary, Periodica Politechnica - Civil Engineering 48 (2004), no. 1-2, 115-130.

14 Czyczuła W, Bogacz R, Mechanics of track structure with Y-shaped steel sleepers in sharp curves, Applied Mechanics and Materials 9 (2008), 71-88, DOI 10.4028/www.scientific.net/AMM.9.71.

15 Szabó J, Kazinczy L, Kutatási jelentés a kis sugarú ivekben épített, ágyazatragasztással stabilizált betonaljas, valamint a biztonsági sapkákkal megerösített betonaljas, zúzottkő ágyazatú hézagnélküli vágányok stabilitás és igénybevételi vizsgálatáról, BME Út és Vasútépítési Tanszék, Budapest, 2009.

16 Liegner N, Kutatási jelentés az Y-aljakkal épített zúzottkó ágyazatú vágány üzemi vizsgálatáról, BME Út és Vasútépítési Tanszék, Budapest, 2009. 